\title{
Liver histology in the arthrogryposis multiplex congenita, renal dysfunction, and cholestasis (ARC) syndrome: report of three new cases and review
}

\author{
S P Horslen, O W J Quarrell, M S Tanner
}

\begin{abstract}
We report three cases from two unrelated families of infants with arthrogryposis multiplex congenita, cholestatic jaundice, and renal Fanconi's syndrome. In both families the parents were consanguineous. All three children died by 7 months of age. This association was first reported in 1973 by Lutz-Richner and Landolt and again in another family by Nezelof et al in 1979. However, because of differing liver histology the two sibships were considered to have two separate conditions. Based on the histological findings in one of our cases we propose that all cases described so far represent variation within a single syndrome.
\end{abstract}

(f Med Genet 1994;31:62-64)

The association between arthrogryposis multiplex congenita, cholestatic liver disease, renal tubular acidosis, and death in infancy has been reported previously. Since the first report by Lutz-Richner and Landolt ${ }^{1}$ in 1973, four other similarly affected families have been reported. The cases described so far have been divided into two separate groups on the basis of hepatic histology. The first group has paucity of intrahepatic bile ducts and giant cell transformation of hepatocytes. ${ }^{12}$ The other condition has pigment deposition in liver cells and marked cholestatis. ${ }^{3-5}$ We describe three further cases from two families and show hepatic histological features in one of the cases compatible with both groups.

\section{Case reports}

CASE 1

Department of
Paediatrics, Sheffield
Children's Hospital,
Sheffield S10 2TH,
UK.
S P Horslen
M S Tanner
Department of
Medical Genetics,
Langhill, Sheffield,
UK.
O W J Quarrell
Correspondence to
Dr Horslen.
Received 21 May 1993.
Revised version accepted for
publication 23 June 1993.

Case 1, the first born child of healthy, consanguineous Pakistani parents, was born at 41 weeks' gestation after a normal pregnancy and delivery, weighing $2575 \mathrm{~g}$. He was noted to have low set ears and arthrogryposis of his lower limbs which consisted of bilateral calcaneovalgus, fixed flexion deformities at the hips and knees, and dislocated hips (fig 1).

On the third day after birth he developed profuse diarrhoea and a metabolic acidosis which persisted even after the diarrhoea had resolved. At 7 days a conjugated hyperbilirubinaemia was noted.

Fanconi's syndrome was diagnosed based on the demonstration of renal tubular acidosis, glycosuria in the absence of hyperglycaemia, generalised amino aciduria, and gross phosphaturia with a fractional phosphate excretion of 0.63 (normal $<0.15$ ).

He was also noted to pass very large quantities of dilute urine in spite of plasma hypertonicity. Hypernatraemia was particularly troublesome when sodium bicarbonate was used to treat the renal tubular acidosis. Urine osmolality was greater than $310 \mathrm{mmol} / \mathrm{kg}$. Nephrogenic diabetes insipidus was confirmed by administering a parenteral dose of desmopressin (400 $\mathrm{ng}$ ) which failed to produce a rise in urine concentration. Treatment with chlorothiazide $(10 \mathrm{mg} / \mathrm{kg}$ three times daily) did not produce a decrease in urine output, but it did increase the urinary sodium losses enabling adequate treatment of the metabolic acidosis with sodium bicarbonate. Total fluid requirements remained at $300 \mathrm{ml} / \mathrm{kg} /$ day.

Cholestasis persisted. Metabolic and infective causes of neonatal liver disease were excluded and there were no features to suggest Alagille's syndrome. Cytogenetic analysis was also normal. Abdominal ultrasound showed normal liver and bile ducts. However, there was no excretion of technetium labelled methylbromo-iminodiacetic acid into the duodenum, after intravenous injection, up to 24 hours later suggesting biliary obstruction. Percutaneous liver biopsy showed cholestasis, lipofuscin deposition, occasional multinucleate forms, and paucity of intrahepatic bile ducts confirmed with immunohistochemical staining for cytokeratin which specifically identifies bile duct epithelium (fig 2). Fat malabsorption continued despite feeding with a formula feed high in medium chain triglycerides and the addition of ursodeoxycholic acid $(15 \mathrm{mg} / \mathrm{kg})$.

With this supportive treatment and dietary supplementation, consisting of glucose polymer and medium chain triglyceride (MCT) oil, he began to gain weight and remained biochemically stable. However, at the age of 7 months he developed a chest infection to which he succumbed. Negative bacterial cultures, a lymphocytosis, and lack of response to broad spectrum antibiotics suggested a viral aetiology. Consent for necropsy was withheld.

\section{CASE 2}

Case 2 was a male born at 42 weeks' gestation to healthy, consanguineous Asian parents. The pregnancy was complicated by a raised $\alpha$ fetoprotein, but amniocentesis was refused. Birth 

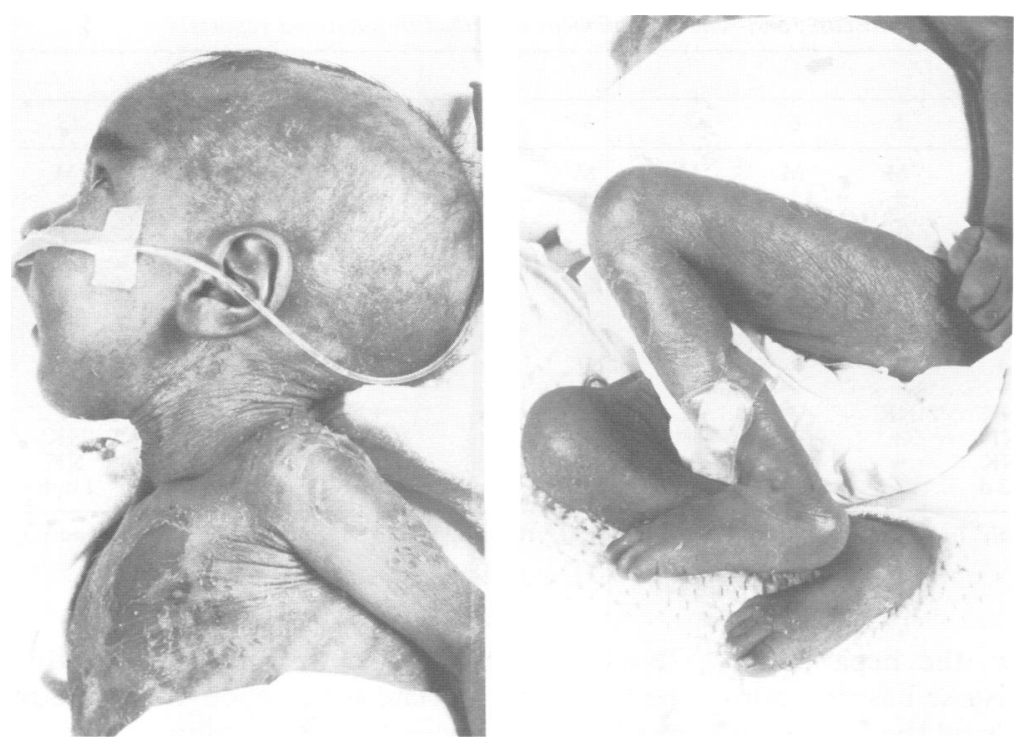

Figure 1 Case 1 aged 4 months. a metabolic acidosis was noted and the infant had evidence of Fanconi's syndrome with generalised amino aciduria, glycosuria, and hyperchloraemia.

An echocardiogram showed a small secundum atrial septal defect. No abnormality was found on cerebral ultrasound or detailed ophthalmological examination. Cytogenetic analysis was normal. Metabolic and infective causes of liver disease were excluded.

This infant received supportive treatment but died at the age of 7 months. There was no necropsy.

\section{CASE 3}

A male sib of case 2 was born at term by elective caesarian section. Serial antenatal ultrasound scans had suggested abnormalities in the third trimester with evidence of oligohydramnios and arthrogryposis. Apgar scores were 6 and 9 at one and five minutes respectively and birth weight was $2950 \mathrm{~g}$. At birth he had contractures of the hips and knees and talipes of the feet and ankles and muscular calcification was noted on radiographs. The ears were described as large but low set. He had a small chin with full lips.

By day four he had developed metabolic acidosis and jaundice. The acidosis was considered to be renal tubular in origin and was associated with generalised amino aciduria. IDA excretion did not occur, suggesting biliary obstruction. He also developed right parotitis. A decision was made to treat him symptomatically and he died at home aged 1 month. Again, necropsy was not undertaken. were not dilated, and an IDA excretion scan showed no evidence of bile flow. On day seven

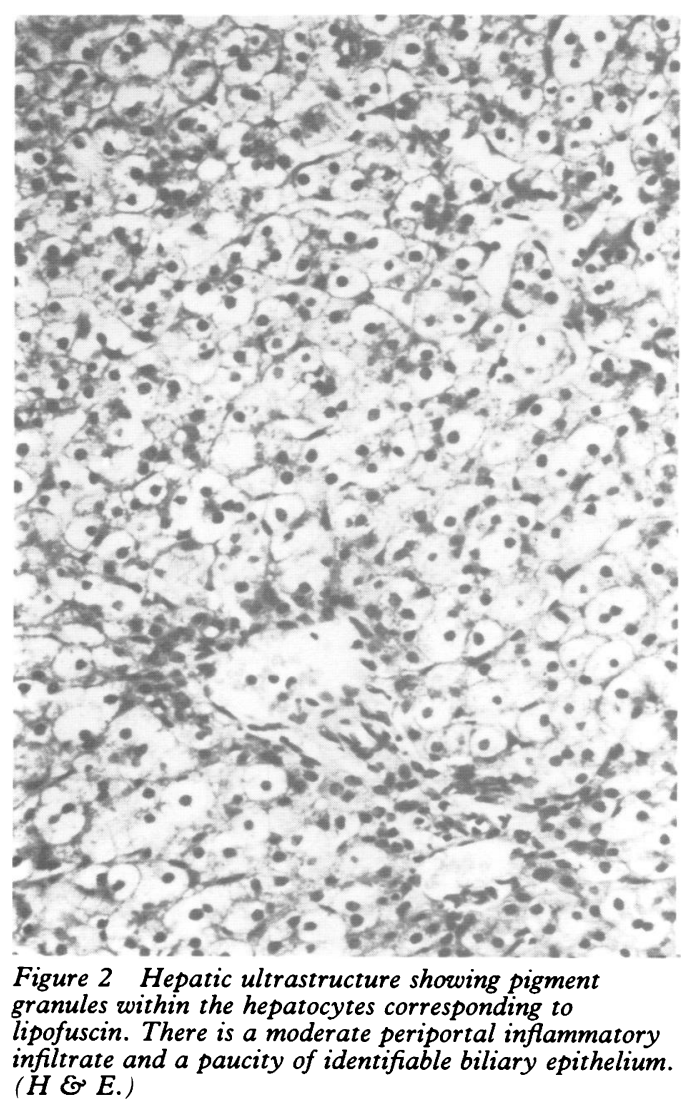

In 1973 Lutz-Richner and Landolt ${ }^{1}$ reported two sibs of consanguineous parents who had arthrogryposis, hepatobiliary disease, and renal dysfunction. Eight further cases have been reported to date (table). In the second report of a sibship with this association of features, Nezelof et $a l^{3}$ suggested $\mathrm{X}$ linked inheritance for the condition. However, the occurrence of affected male and female sibs in later case reports, together with parental consanguinity, suggests autosomal recessive inheritance as the most likely mechanism. ${ }^{45}$

All reports which looked at the neuromuscular pathology have concluded that the deformities were the result of neurogenic muscular atrophy with rarifaction of the motor neurones of the anterior horns of the spinal cord..$^{3-5} \mathrm{Also}$, identical renal pathological findings of renal tubular degeneration with nephrocalcinosis have been described in previous case reports. ${ }^{124}$ However, Lutz-Richner and Landolt $^{1}$ and Mikati et $a l^{2}$ describe paucity of intrahepatic bile ducts and multinucleate transformation of hepatocytes in their patients, whereas the findings of Nezelof $e t a l^{\beta}$ and subsequently Di Rocco $e t a l^{4}$ and Saraiva et $a l^{5}$ changes with cholestasis. In view of these differing histological findings, Di Rocco et $a l^{4}$ suggested that two separate conditions were

\section{Discussion} were of Dubin-Johnson-like pigmentary 
Major features of infants with arthrogryposis multiplex, cholestatic liver disease, and renal impairment described in published reports.

\begin{tabular}{|c|c|c|c|c|c|c|c|c|c|c|c|c|c|}
\hline & \multicolumn{13}{|l|}{ Case } \\
\hline & 1 & 2 & 3 & 4 & 5 & 6 & 7 & 8 & 9 & 10 & 11 & 12 & 13 \\
\hline $\begin{array}{l}\text { Sex } \\
\text { Consanguineous parents } \\
\text { Infant death in family } \\
\text { Failure to thrive } \\
\text { Low set ears } \\
\text { Arthrogryposis } \\
\text { Anterior horn cell depletion } \\
\text { Cholestatic jaundice } \\
\text { Lipofuscin deposition } \\
\text { Intrahepatic bile duct paucity } \\
\text { Renal Fanconi's } \\
\text { Nephrocalcinosis } \\
\text { Renal tubular cell degeneration } \\
\text { Age at death }\end{array}$ & $\begin{array}{l}\text { M } \\
+ \\
+ \\
+ \\
\text { NK } \\
+ \\
\text { NK } \\
+ \\
- \\
+ \\
+ \\
+ \\
+ \\
4 \text { mth }\end{array}$ & $\begin{array}{l}\text { M } \\
+ \\
+ \\
+ \\
\text { NK } \\
+ \\
\text { NK } \\
+ \\
+ \\
+ \\
+ \\
+ \\
+ \\
3.5 \mathrm{mth}\end{array}$ & $\begin{array}{l}\text { M } \\
+ \\
+ \\
+ \\
\text { NK } \\
+ \\
\text { NK } \\
+ \\
\text { NK } \\
\text { NK } \\
\text { NK } \\
\text { NK } \\
\text { NK } \\
2 \text { mth }\end{array}$ & $\begin{array}{l}\text { M } \\
+ \\
+ \\
+ \\
\text { NK } \\
+ \\
\mathrm{NK} \\
+ \\
+ \\
+ \\
\mathrm{NK} \\
\mathrm{NK} \\
\mathrm{NK} \\
12 \mathrm{~d}\end{array}$ & $\begin{array}{l}\text { M } \\
+ \\
+ \\
+ \\
\text { NK } \\
+ \\
+ \\
+ \\
+ \\
- \\
\text { NK } \\
+ \\
+ \\
22 \mathrm{~d}\end{array}$ & $\begin{array}{l}\text { M } \\
+ \\
+ \\
+ \\
\text { NK } \\
+ \\
+ \\
+ \\
+ \\
+ \\
+ \\
+ \\
+ \\
+ \\
3.5 \text { mth }\end{array}$ & $\begin{array}{c}\text { M } \\
+ \\
+ \\
+ \\
+ \\
+ \\
\text { NK } \\
+ \\
+ \\
+ \\
+ \\
+ \\
+ \\
4 \text { mth }\end{array}$ & $\begin{array}{c}\text { M } \\
+ \\
+ \\
+ \\
+ \\
+ \\
\text { NK } \\
+ \\
\text { NK } \\
\text { NK } \\
+ \\
\text { NK } \\
\text { NK } \\
2.5 \mathrm{mth}\end{array}$ & $\begin{array}{c}\text { M } \\
+ \\
+ \\
+ \\
\text { NK } \\
+ \\
+ \\
+ \\
+ \\
+ \\
+ \\
+ \\
+ \\
2 \text { mth }\end{array}$ & $\begin{array}{c}\text { F } \\
+ \\
+ \\
+ \\
\text { NK } \\
+ \\
+ \\
+ \\
+ \\
+ \\
+ \\
+ \\
+ \\
2 \text { mth }\end{array}$ & $\begin{array}{c}\text { M } \\
+ \\
- \\
+ \\
+ \\
+ \\
\text { NK } \\
+ \\
+ \\
+ \\
+ \\
\text { NK } \\
\text { NK } \\
7 \text { mth }\end{array}$ & $\begin{array}{c}\text { M } \\
+ \\
+ \\
+ \\
+ \\
+ \\
\text { NK } \\
+ \\
\text { NK } \\
\text { NK } \\
+ \\
\text { NK } \\
\text { NK } \\
7 \text { mth }\end{array}$ & $\begin{array}{c}\text { M } \\
+ \\
+ \\
+ \\
+ \\
+ \\
\text { NK } \\
+ \\
\text { NK } \\
\text { NK } \\
+ \\
\text { NK } \\
\text { NK } \\
1 \text { mth }\end{array}$ \\
\hline
\end{tabular}

Cases 1 and 2 Lutz-Richner and Landolt, ${ }^{1} 3,4,5$, and 6 Nezelof $e t a l,{ }^{3} 7$ and 8 Mikati et al, ${ }^{2} 9$ Di Rocco et al, ${ }^{4} 10$ Saraiva et al, ${ }^{5} 11,12$, and 13 present report.

$+=$ present, $-=$ absent, $\mathrm{NK}=$ not known.

being described. However, the hepatic pigment in Dubin-Johnson disease has the staining properties of lipofuscin and the findings of cholestasis, multinucleate cells, lipofuscin deposition, and intrahepatic biliary hypoplasia in our first patient suggest that there is overlap between all the cases described so far. Both bile duct paucity and lipofuscin deposition can be seen in a wide range of liver disease and both features probably represent non-specific changes resulting from a variety of insults to the liver. Similarly, a common insult may produce both lesions but the degree of each may vary from person to person and may depend on the site from which the liver biopsy is taken and the stage in the evolution of the pathological process at which the specimen was obtained. We propose that all cases represent the same condition. Although the genetic mechanism is clear, the underlying metabolic abnormality is unknown. Although the recent reports have spoken of this phenotype as
'Nezelof's syndrome', we suggest that this term is inappropriate as this eponym is already used to describe a form of thymic immunodeficiency; instead we suggest the acronym ARC syndrome.

We would like to acknowledge $\operatorname{Dr} R$ Mueller for first making the diagnosis in case 1 and $\mathrm{Mr}$ Anderton and Dr Murphy for referring the patients to us.

1 Lutz-Richner AR, Landolt RF. Familiare Gallengangsmissbildungen mit tubularer Niereninsuffizienz. Helv Paediatr Acta 1973;28:1-12.

2 Mikati MA, Barakat AY, Sulh HB, Der Kaloustian VM. Renal tubular insufficiency, cholestatic jaundice and multiple congenital anomalies - a new multisystem syndrome. Helv Paediatr Acta 1984;39:463-71.

3 Nezelof C, Dupart MC, Jaubert F, Eliachar E. A lethal familial syndrome associating arthrogryposis multiplex congenita, renal dysfunction, and a cholestatic and pigmentary liver disease. $\mathcal{F}$ Pediatr 1979;94:258-60.

4 Di Rocco M, Reboa E, Barabino A, et al. Arthrogryposis, cholestatic pigmentary liver disease and renal dysfunction. Am $₹$ Med Genet 1992;37:237-40.

5 Saraiva JM, Lemos C, Gonçalves I, Carneiro F, Mota HC. Arthrogryposis multiplex congenita with renal and hepatic abnormalities in a female infant. $\mathcal{F}$ Pediatr 1990;117:761-3. 